\title{
SAJEST
}

http://dx.doi.org/10.4314/sajest.v4i1.39813

Original Article

Open Access

Received: June 2014 / Accepted: 1 August 2016

Published online: June 2017

\section{Causes of wildland fires and factors that influence knowledge of fire management at Crofton village, Makoni District, Zimbabwe}

Choga Dyke and Nyamadzawo George*

\begin{abstract}
Wildland fires are a threat to the conservation of biodiversity and human life. In Zimbabwe, the newly re-settled smallholder farmers are perceived as the major drivers of wildland fires. A survey was conducted in Crofton Village Ward 38 of Makoni District in Zimbabwe to determine farmers' knowledge on the causes of wildland fires and factors that influence their knowledge on the management of wildland fires. Randomised purposive multistage sampling was used to select $60 \%$ of the total population in the study area. Data processing and analysis was done using the Statistical Package for the Social Sciences (SPSS) version 21.0 of 2012 to analyse the relationship between the dependent variable (farmers' knowledge of wildland fire management) and independent variables (sex, age, level of education and period of stay in the village. Farmers revealed that land clearing, poor disposal of ashes, brick moulding and arson were the chief causes of wildland fires. There was a significant $(\mathrm{p}<0.05)$ relationship between period of stay in the village
\end{abstract}

\footnotetext{
Corresponding Author :

Dyke Choga, G Nyamadzawo* Department of Environmental Science, Bindura University of Science Education, P. Bag 1020, Bindura, Zimbabwe. E-mail: gnyama@yahoo.com
}

with farmer's knowledge of management of wildland fires. Farmers' knowledge on wildland fire management was influenced by period of stay and exposure to wildland fires in the village. Farmers with a longer period of stay in the study area were more knowledgeable than those with a shorter period. Gender and age had an effect on farmer's knowledge about causes of wildland fires and men apparently had more knowledge and experience with wildland fire management. Human activities were responsible for most of the wildland fires. Resettled farmers, farmers with primary level and those with no formal education had limited knowledge on wildland fire management. It was recommended that effective wildland fire awareness programmes be put in place to improve farmer knowledge and wildland fire management skills.

Keywords: Wildland fires, anthropogenic activities, resettled smallholder, management.

\subsection{INTRODUCTION}

Wildland fires are a major problem in the savanna region because they occur too frequently thereby causing land degradation, loss of biodiversity, food insecurity, loss of life, destruction of property and 
emission of greenhouse gases which cause global warming and climate change (Svotwa et al., 2007; Amissah et al., 2010; Nyamadzawo et al., 2013). According to the EMA (2014) between 2010 and 2014 Crofton village lost approximately 3000 ha to wildland fires on an annual basis. Forests are under the highest threat from wildland fires though they play an important role in the economy, social wellbeing of people and the environment. In Zimbabwe, forests contribute $3 \%$ to Gross Domestic Product (GDP) (Forestry Commission of Zimbabwe, 2011).

Several reasons have been cited as causes of wildland fires. Human beings were reported to cause $95 \%$ of wildland fires in Southern Africa, while natural fires have become rare (Nkomo et al., 2009). However, farmers in Cashel Valley cited agricultural activities as the major factor for wildland fires (Nkomo, 2009). In Zimbabwe farmers use fires to burn plant residues and clear virgin land during land preparation (Svotwa et al., 2007). They also burn plant residues to kill pests especially in grazing lands (Nkomo et al., 2009). In the Chegutu area, farmers perceived hunting as the major cause of wildland fires (Svotwa et al., 2007). Hunting and burning by hunters who want to flash out wild animals are activities that also cause wildland fires, in addition to bee smoking, throwing of burning cigarette stubs, lighting of fires by resting motorists on the roadside, poor disposal of ashes and arson which have also been reported to be among major causes of wildland fires (Svotwa et al., 2007; Nkomo et al., 2009; EMA, 2011).

Korem, (1985), assumed that farmers have limited knowledge in fire management and do not make any effort to curb the incidence of wildland fires, while Amissah et al. (2010) suggested that farmers have limited knowledge on fire management and this resulted in fires getting out of control. Amissah et al., (2003) argues that, since farming is dynamic and is constantly fed by farmers' knowledge and perceptions, farmers should have an appreciation of fire-related causes to enable them cope with increasing incidences of wildfires in the agricultural landscapes. Farmers have knowledge on the ways of managing wildland fires but their ideas need to be supported (Amissah et al., 2003). A study conducted by Absher et al., (2009) on who is responsible for fire management found that the responsibility is shared between farmers and environmental managers.

Documented information on factors influencing the farmers' knowledge levels in wildland fire management in Zimbabwe is currently scanty. For example Amissah et al., (2010) researched on the perspectives of farmers on the management of wildland fires but did not look into factors that influence their knowledge. Such factors form the basis for successful wildland fire management and if not considered during awareness campaigns, meetings and workshops the goal of reducing wildland fires will not be achieved. There is therefore need to assess and understand the causes of wildland fires and the factors that influence farmers' knowledge on wildland fire management.

Knowledge of farmers can be influenced by several factors such as age, gender, level of education and period of stay in an area or exposure to wildland fires. Land owner's knowledge towards prescribed burning and suppression of wildland fires is associated with previous experiences (McCaffrey, 2008; Toledo et al., 2013). Those with more years of stay in an area have more experience and skills to manage wildland fires than those with a shorter period of stay. Morris (1991) cited gender as a 
factor that can influence people's knowledge and adoption of new technology. Mostly women are forgotten in technology adoption and transfer. Cultural systems reinforced this by insisting on women to remain at home while husbands attend meetings, workshops and seminars, however they do not teach women what they have learnt (Mazvimavi et al., 2009). Education is a major factor that can influence the level of knowledge of fire management. The farmer's level of education determines ones' appreciation for managing natural resources (Norman, 2005). The farmer's education background is an important factor that determines the readiness to accept and properly apply technologies (Swamson et al., 1984).

Wildland fires continue to be a menace in Makoni District just like in most parts of the country. The relevant environmental authorities such as EMA and the Forestry Commission of Zimbabwe have been making relentless efforts to minimise the occurrences of wildland fires but without much success. There is need for a paradigm shift in wildland fire management strategies in Zimbabwe, which should encompass the level of understanding that farmers on causes of wildland fires in their localities, and to assess how much knowledge they have in practical wildland fire management. This study therefore examined farmers' knowledge on the causes of wildland fires and factors that influence their knowledge on the management of wildland fires in Crofton village.

\subsection{MATERIALS AND METHODS}

\subsection{Study Area}

The study was conducted at Crofton Village in Ward $38\left(18.47295^{\circ} \mathrm{S}, 32.12705^{\circ} \mathrm{E}\right.$ and altitude 1 $468 \mathrm{~m}$ above sea level) in Makoni District, Zimbabwe. Makoni district is in Natural Region
(II) with annual rainfall between $750 \mathrm{~mm}$ to 1000 $\mathrm{mm}$. The soils is the study are were grey paraferallitic soils (Vincent and Thomas, 1960). The mean annual temperature of $24^{\circ} \mathrm{C}$ to $30^{\circ} \mathrm{C}$ (Goudie, 1984). It is characterised by hot wet summers and cool dry winters. Wet periods are experienced from November to March and cool dry periods are from April to July, the period when trees in the area lose their leaves in response to winter. These weather conditions especially between July and October are conducive for wildland fire outbreaks.

The main crops grown in the village are maize (Zea mays L.), ground nuts (Arachis hypogaea L.) and tobacco (Nicotiana tabacum L) (Mtambanengwe et al., 2012). The area is characterised by common thatching grass Hyparrhenia hirta (L.) growing to a height of about $2.5 \mathrm{~m}$. It is characterised by Miombo woodland dominated by tree species such as Brachystegia spiciformis (Benth), Brachystegia boehmii (Taubert) and Julbernardia globiflora (Benth) (Mtambanengwe et al., 2012). Lantana camara an alien species is also found in the study area. There are 63 resettled farmers who moved into the area during the Fast Track Land reform programme in 2002.

\subsection{Data collection}

Purposive sampling was used to select the study area. It was based on selecting the district with the highest percentage of wildland fires in Manicaland Province. This district recorded $19 \quad 673.3$ ha (46.6\%) out of 42203.7 ha which was destroyed by wildland fires (EMA, 2014). Purposive sampling was also used to select Ward 38 which had the highest frequency of wildland fires. Households surveyed were randomly selected until a sampling of $60 \%$ was reached. A questionnaire with both semi-structured and open ended questions was 
administered to the selected farmers and focus group discussions were also held. In addition, other methods such as direct observation and key informant interviews were also used during data collection. A total of 10 key informants from EMA, Forestry Commission, Makoni Rural District Council, Agritex, village Committees and District Administrator (DA) were interviewed.

\subsection{Data analysis}

Data were analysed using SPSS version 21.0 (2012) to categorise farmers' perceptions on the causes of wildland fires. The causes were ranked according to their frequency from most common to the least common. Ordinal regression was used to analyse factors that influence farmers' knowledge on wildland fire management. From the responses knowledge of farmers towards management of wildland fires was considered as the dependent variable and independent variables were level of education, period of stay in the village, gender and age of farmers. A weighted dependent variable was generated using the following equation.

$\mathrm{Y}=\mathrm{a}+\mathrm{b} 1 \mathrm{X} 1+\mathrm{b} 2 \mathrm{X} 2+\mathrm{b} 3 \mathrm{X} 3+\mathrm{e}$

Where, $\mathrm{Y}=$ dependent variable (knowledge level of farmers on wildland fire management) $\mathrm{a}=$ constant, $\mathrm{b}=$ regression co-efficient $\mathrm{X} 1=$ age, $\mathrm{X} 2=$ education level, $\mathrm{X} 3$ = period of stay in the village, $\mathrm{e}$ $=$ error term.

\subsection{RESULTS}

\subsection{Causes of wildland fires}

Approximately $83.8 \%$ of the farmers identified poor disposal of ashes from homesteads as the major cause of wildland fires in Crofton village, followed by brick moulding (62.2\%), arson $(59.5 \%)$ and land clearance $(52.8 \%)$. Bricks were in high demand for construction. Smoking was cited as a major cause of wildland fires by $38 \%$ of the respondents, while hunting was cited by $13.5 \%$ respondents (Figure 1).

\subsection{Factors that influence farmers' knowledge on wildland fire management}

There was a significant relationship between period of stay and farmers knowledge of wildland fire management $(\mathrm{p}<0.05)$. The longer the farmer had resided in the village, and the more exposure they have had to wildland fires, the more knowledgeable they were on wildland fire issues. Farmers who had been in the village for longer (between 11 and 15 years) were more knowledgeable than those who had been in the village for between 6 and 10 years and for less than 5 years.

Gender had an effect on level of knowledge on wildland fires amongst villagers. Men were more knowledge and experienced with wildland fire management compared to women. However, level of education had a significant effect on farmers' knowledge on wildland fire management. Farmers with primary level and those with no formal education had limited knowledge on wildland fire management. Farmers who attended secondary school were better knowledgeable than those who only attended primary school and those who never attended school. There were no significant differences between age categories and knowledge regarding wildland fire management, as all adults interviewed showed significant knowledge about the causes of wildland fires (Table 1).

\subsection{DISCUSSION}

Most wildland fires in Crofton Village were caused by anthropogenic activities. Anthropogenic activities caused fires due negligence or accident, 


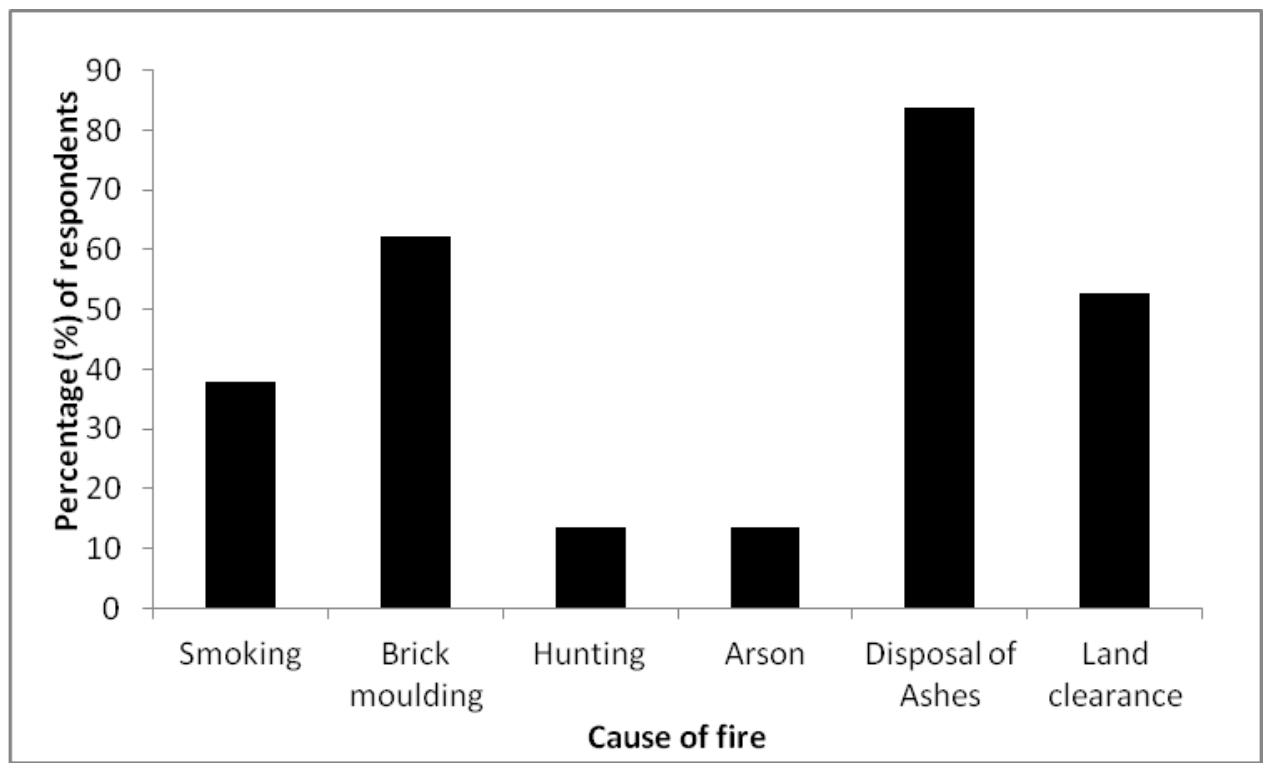

Figure 1. Causes of wildland fires in Crofton Village in Makoni district of Zimbabwe.

Table: 1 Relationship between dependent (knowledge of farmers on wildland fire management) and independent variables (sex, age, level of education and period of stay).

\section{Table 1}

\begin{tabular}{llll}
\hline Parameter & Category & Standard Error & \multicolumn{1}{c}{ P Values } \\
\hline Age & 16-30 years & 1.577 & 0.96 \\
& 31-50 years & 1.563 & 0.47 \\
Gender & $51^{+}$years & $\cdot$ &. \\
Male & 1.114 & 0.79 \\
Period of stay & Female & $\cdot$ & $\cdot$ \\
& 1-5 years & 1.670 & 0.10 \\
Level of education & 6-10 years & 0.000 & $\cdot$ \\
& 11-15 years & $\cdot$ & $\cdot$ \\
& Non and Primary & 0.00 & 0.42 \\
& Secondary & 1.454 & $\cdot$ \\
\hline
\end{tabular}

anthropogenic activities such as poor disposal of ashes, clearing land for agriculture, hunting, and arson were the major causes of wildland fires. The issue of poor disposal of ashes as a major cause of wildland fires was only perculiar to Crofton village. Hot ashes disposed in waste dumps accelerated the ignition of fires (Bird, 2009). However, other similar studies, e.g. Nkomo et al. (2009) and Nyamadzawo et al., (2013) land clearance and hunting as top causes of wildland fires.
Key informant interviews revealed similar causes of wildland fires to those highlighted by the farmers. However, the key informants ranked land clearance and hunting of wildlife as the major causes of wildland fires. Environmental Management Agency (EMA) also reported that farmers were reluctant to construct fireguards which resulted in rapid spread of wildland fires. Furthermore, many farmers who constructed fireguards did not make them 9 metres wide as stipulated in the EMA legislation. The main reason 
for this was cited as lack of capacity by most smallholder farmers to construct fire guards and lack of enforcement and monitoring by EMA.

In Crofton village, hunting was not the top major cause of wildland fires, and the depletion of wildlife population was cited by respondents as the major reason. Some of the factors that may have pushed wild animals away from Crofton include shortage of forage and habitat which were destroyed by wildland fires and human expansion into grazing and forested areas. This observation was supported by Nkomo et al., (2009) who argued that wildland fires destroy pastures and force animals to migrate. However, in contrast to the above, most of the studies which were conducted in resettlement areas before 2010 singled out hunting as the major cause of wildland fires (Panzer and Schwartz, 2000; Svotwa et al., 2007).

Beekeeping was not common in the study area and the major reason for low bee keeping was cited as frequent destruction of hives by wildland fires. As a result of low numbers of hives and bee keeping activities, bee smoking was not cited as a major cause of wildland fires. These results contradict those by Svotwa et al. (2007) and Nyamadzawo et al., (2013) who argued that honey harvesting was a major cause of wildland fires.

Brick moulding was one of the major causes of wildland fires in Crofton. Brick firing season often coincides with the dry season, when conditions conducive for wildland fire spread are available, such as high fuel load and high wind speed. During the first two days of firing bricks, kiln openings are left open to allow oxygen to enter to support combustion. Due to high wind speed, the openings of kilns allows hot ashes and flames to be blown out which causes fires if they reach nearby grass that subsequently catch fire resulting in wildland fires.

Conflict between land owners and workers is one of the major causes of arson. This is consistent with observations by Nyamadzawo et al., (2013) which articulated that non-payment of farm employees' or low remuneration is contributing to arson. Another cause of arson was claimed to have been jealousy among farmers who want their neighbours to be fined by EMA. The farmers who are charged for failing to construct standard fireguards also tend to start fires outside their farms or in grazing areas as a way of protesting against environmental law enforcement agencies such as EMA. The research findings are similar to those by Bond (2001) who stated that arson burns are common sometimes due to a protest against state authority.

Due to inadequate farming equipment, some farmers are still using the slash and burn technique to clear the land for farming. Land clearing using fire is decreasing due to the fact that most of the arable land is almost taken up and occupied. Nevertheless, this study showed that slash and burn farming is still practiced but at a lower scale. These observations are supported by Nyamadzawo et al. (2013) and FAO (2010) who noted that many smallholder farmers with inadequate resources and equipment to use in land preparation tend to use fire since it is cheap.

Farmers who had stayed in the village for a long period had more knowledge regarding wildland fire management acquired during awareness campaigns, meetings and workshops. Farmers who attend more meetings have more knowledge. In addition, farmers with longer period of stay have witnessed more wildland fire impacts such as loss of life, property, livestock, houses and crops. Consequently, this could have influenced their 
eagerness to learn more about wildland fire management methods so that they can mitigate the impacts of wildland fires. This concurs with the research conducted by McCaffrey (2008); Toledo et al., (2013) which showed that knowledge of farmers is influenced by their previous experiences.

Farmers with 1-5 years period of stay have migrated from different areas, $70 \%$ came from urban areas, $15 \%$ from nearby villages and $15 \%$ from rural areas. Therefore there is high probability that farmers with 1-5 years period of stay have come into Crofton village without knowledge about wildland fire management. In addition, the newcomers have attended few or no environmental meetings and workshops. Level of education has an influence on wildland fire management. Attending tertiary education will allow one to know wildland fire management methods while not even going to school or to quit school at primary level will affect their understanding of wildland fire management.

Therefore, it is recommended that the school curricula should incorporate wildland fire issues from primary level. Those who did not go to school and those who quit school at primary level are less likely to read newspapers, fliers and textbooks where information on wildland fire can be disseminated. Similar research conducted by Norman (2005) showed that education level affects knowledge on managing natural resources.

\subsection{CONCLUSIONS AND RECOMMENDATIONS}

Wildland fires are causing negative impacts to human life, flora and fauna in Crofton village of Makoni District in Zimbabwe has a negative impact on the biodiversity and ecosystem. Human activities are responsible for causing most of the wildland fires in the in Crofton village. Although, the rate of using fire in agricultural activities is decreasing, however, due to poverty and lack of knowledge on managing wildland fires, farmers are still using fire for land preparation. In Crofton village, poor disposal of ashes, brick moulding and arson are chief causes of wildland fires. Knowledge of farmers on wildland fire management was influenced by period of stay in the village. The level of education, had a bearing on wildland fire management. Resettled farmers, farmers with primary level and those with no formal education, as well as women had limited knowledge on wildland fire management. This can be explained by gender inequality enshrined is communities where the girl child is given less access to education compared to the boy child.

It is recommended that more wildland fire awareness programmes be put in place. In addition village wildland fire-fighting committee be put in place in resettlement areas and these should be inclusive to include women.

\subsection{REFERENCES}

Absher, J.D. et al., 2009. Residents' responses to wild land fire programs: a review of cognitive and behavioural studies. U.S. Department of Agriculture, Forest Service, Pacific Southwest Research Station, Albany, California, USA.

Acton, C., Miller, R. 2009. SPSS for social scientists, 2nd edition, Basingstoke: Palgrave Macmillan.

Amissah, L. 2003. Effects of Wildfire on Farming System Dynamics in the Fire Prone Forest Belt of Ghana, MPhil, Thesis knust.

Amissah, L. et al., 2010. Wildlife incidence and management in the forest transition zone of Ghana, Journal of Forestry 26: 61-73. 
Bird, D.K. 2009. The use of questionnaires for acquiring information on public perception of natural hazards and risk mitigation - a review of current knowledge and practice, Natural Hazards and Earth System Sciences, Copernicus Publications, London.

Bond, W.J., Midgley, J.J. 2001. Ecology of sprouting in woody plants: the persistence niche. Trends in Ecology and Evolution 16: 45-51.

Environmental Management Agency. 2011. Fire assessment report, Environmental Management Agency, Benaby Printing and Publishing, Harare.

Environmental Management Agency (EMA). 2014. Wildland Fire Annual Report for Manicaland Province, EMA, Zimbabwe.

FAO. 2010. Global Forest Resources Assessment main report (FAO), Rome, Available from: [http://www.fao.org/docrep/013/i1757e/i1757e.pdf]

Forestry Commission. 2011. Vegetation cover map of Zimbabwe, Forest Research Centre, Highlands, Harare, Zimbabwe.

Goudie, M. 1984. The Human impact. Man's role in Environmental Change, Basil, Blackwell, Oxford.

Korem, A. 1985. Bush Fire and Agricultural Development in Ghana. Ghana Publishing Corporation: 122-158.

Panzer, R., Schwartz, M. 2000. Effects of management burning on prairie insect species richness within a system of small, highly fragmented reserves. Biological Conservation 96: 363-369.

Malmsheimer, R.W. et al., 2011. Managing Forests because Carbon Matters: Integrating Energy,
Products, and Land Management Policy. Journal of Forestry 109: (7).

Mazvimavi, K. et al., 2009. Conservation Agriculture Practices and Adoption by Smallholder Farmers in Zimbabwe, International Crop Research Institute for the Semi-Arid Tropics (ICRISAT), Bulawayo.

McCaffrey, S. 2008. Understanding public perspectives of wildfire risk, Wildfire risk, human perceptions and management implications. Resources for the Future, Washington, D.C.

Morris, M. et al., 1998. Maize Seed Industries in Developing Countries, Technical Economics, and Policy Issues, Boulder, Colorado, USA, pp. 35 54.

Mtambanengwe, F. et al., 2012. Climate change and variability: Smallholder farming communities in Zimbabwe portray a varied understanding, Journal of African Crop Science 20(2): $227-241$.

Nkomo, G.V., Sassi, M. 2009. Impact of veld fires on land on resettlement farmers in Cashel Valley Cashel Valley in Zimbabwe, Natural Resources, Agricultural Development and Food security, International Research Network 9 (2): 1-17.

Nyamadzawo, G., Kanda, A., Kuhlande. A., Masona, C. 2013. Understanding the causes, socioeconomic, environmental impacts and Management of veld fires in tropical Zimbabwe. Fire Science Reviews 2: 2

O’Connell, A. 2006. Logistic regression models for ordinal response variables, Sage Publications, India. 
Svotwa, E., Ndangana, F., Manyanhire, O., Mushava I. 2007. Veld Fire Risk Assessment and Community Based Control Strategy in Norton Farming Area of Zimbabwe. Journal of Sustainable Development in Africa 9 (2): 15205509.

Toledo, D et al., (2013). Social and ecological factors influencing attitudes toward the application of high-intensity prescribed burns to restore fire adapted grassland ecosystems, Journal of Ecology and Society 18(4): 9.

Vincent V, Thomas RG. 1960. An agroecological survey of Southern Rhodesia Part 1: Agroecological survey: Government Printers. Salisbury (Harare).

World Wide Fund. 2001. Fire management manual, Southern Africa Regional Programme Office (SARPO), Harare. 